\title{
Correction to: Joint estimation of intertemporal labor and consumption decisions: evidence from Spanish households headed by working men
}

\section{Antonio Cutanda ${ }^{1} \oplus$. Juan A. Sanchis-Llopis ${ }^{2} \oplus$}

Published online: 3 September 2021

(c) Eurasia Business and Economics Society 2021

\section{Correction to: Eurasian Economic Review https://doi.org/10.1007/s40822-021-00176-3}

In the original publication of the article, the author missed to provide the Acknowledgements. The Acknowledgements is given below in the erratum article:

Acknowledgements This paper received the Best Paper Award in the 33 Eurasian Business and Economics Society (EBES) conference held in Madrid 2020. We are very grateful to the committee. We also thank two anonymous referees and the Editor for their helpful comments and suggestions.

Publisher's Note Springer Nature remains neutral with regard to jurisdictional claims in published maps and institutional affiliations.

The original article can be found online at https://doi.org/10.1007/s40822-021-00176-3.

Juan A. Sanchis-Llopis

sanchisl@uv.es

1 Universidad de Valencia, Valencia, Spain

2 Universidad de Valencia and ERICES, Valencia, Spain 